\title{
Identity of foreign language pre-service teachers to speakers of other languages: Insights from Brazil and Chile $^{1}$
}

\section{Identidad de los profesores que enseñan inglés a estudiantes hablantes en otros idiomas: Perspectivas de Brasil y Chile}

\author{
Renata Archanjo ${ }^{2}$ \\ Malba Barahona ${ }^{3}$ \\ Kyria Rebeca Finardi ${ }^{4}$
}

Citation/ Para citar este Artículo: Archanjo, R., Barahona, M. \& Finardi, K. (2019). Identity of foreign language pre-service teachers to speakers of other languages: Insights from Brazil and Chile. Colomb. Appl. Linguistic. J., 21(1), pp. 62-75.

Received: 10-Nov.-2018 / Accepted: 15-Mar.-2019

DOI: https://doi.org/10.14483/22487085.14086

\begin{abstract}
The aim of this paper is to examine the identity of foreign language $(\mathrm{FL})$ pre-service teachers in two distinct contexts: Brazil and Chile. A multiple case study methodology was used to investigate how foreign language pre-service teachers develop and conceptualize their teacher identity in three different teacher education programs-two in Brazil and one in Chile. The analysis focused on three main issues: emerging identities, the role of foreign language proficiency, and the practicum as a mediating space to develop teacher identity. Results of the two case studies situated in Brazil suggest that FL pre-service teacher identity is shaped by their beliefs on language proficiency. The case study in Chile confirmed that pre-service teachers' identity oscillates between identifying as students and as teachers. Overall, results of the study suggest that FL teacher identity is shaped by notions of legitimization of the teacher's role and language proficiency.
\end{abstract}

Keywords: Brazil, Chile, foreign language teachers, speakers of other languages, teacher identity

\section{Resumen}

El objetivo de este artículo es examinar la identidad de los profesores de idiomas extranjeros (IE) en formación situados en dos contextos: Brasil y Chile. Con ese objetivo, se utilizó una metodología de estudio de caso múltiple para investigar la identidad de profesores de idiomas extranjeros en formación en tres contextos diferentes-dos en Brasil y uno en Chile. El análisis se centró en tres temas principals: las identidades emergentes, el papel del dominio de la lengua extranjera y la práctica pedagógica como un espacio de mediación para desarrollar la identidad

\footnotetext{
1 The second author was supported by a CONICYT-PAI Grant $N^{\circ} 82140007$ by the Chilean Government to undertake the research reported in this paper.

2 renaarchanjo@gmail.com. Universidade Federal do Rio Grande do Norte, Natal, Rio Grande do Norte, Brazil.

3 Malba.barahonad@gmail.com. Pontificia Universidad Católica de Valparaíso,Viña del Mar, Chile.

4 kyria.finardi@gmail.com. Federal University of Espirito Santo, Vitória, Brazil.
} 
docente. Los resultados de los dos primeros estudios de caso realizados en Brasil sugieren que la identidad docente de IE se ve afectada por las percepciones y creencias de profesores sobre la competencia lingüística y el nivel de proficiencia. El estudio de caso realizado en Chile confirmó que la identidad de los profesores oscila entre identificarse como estudiantes y como profesores. En general, los resultados del estudio apuntan a la conclusión de que la identidad del profesores de IE se ve afectada por las nociones de legitimación del rol y el nivel de proficiencia del IE.

Palabras clave: Brasil, Chile, identidad docente, profesores de idiomas extranjeros, hablantes de otros idiomas

\section{Introduction}

Identity is intrinsically embedded in the social hierarchy of our postmodern world particularly since technological globalization has facilitated contact between people, cultures, and languages, thus shortening distances, removing boundaries, and fueling the notion of the world as a global village (Bauman, 1999). Social relations have indeed become more complex as identities tend to be less coherent and stable entities. This is to say that the more diverse and complex human encounters and relationships are, the more multifaceted and plural the roles they assume in individual and in social practices will be.

Yet identities may be the product of social, cultural, or institution instantiation (Weedon, 2004) and subjectivities are constituted by the discourses generated by institutional, social, and cultural practices within historical contexts. Identities are always relational and negotiable (Norton, 2000). Language, seen as more than a linguistic system of signs with regularities and applicability, is a social practice that engages subjects into meaningful exchanges where identities are negotiated and constructed. When social practice is seen in relation to language use and education, particularly in the case of foreign language teachers, their lived experiences, beliefs, and knowledge help them build their identity transforming their practices.
Furthermore, the concept of identity has been used to understand how teachers learn and enact their beliefs and personal theories, and, as such, studies on teacher identity have become commonplace in language teacher education and other related fields (Barkhuizen, 2017). This is not surprising as more and more studies reveal that there seems to be a correlation between stronger teacher identities and higher levels of teaching efficacy. In the context of initial second/foreign/additional (hereafter L2) language teacher education, the growing body of literature also demonstrates that studying who teachers are and how they develop those identities in specific activities is a crucial matter not only to understand the nature of teachers' learning and practices, but also to transform teacher education thus contributing to a local/global society.

In the case of L2 teacher education, teachers are confronted with contested identities confronting themselves as language learners and teachers (Barahona, 2015). In foreign language (FL) contexts, most teachers have learned the foreign language in tertiary education where language proficiency is usually stressed as a key characteristic of foreign language teachers. Foreign language teachers construct their identities shaped by the language experiences they live as permanent language learners. On the other hand, as teachers, they develop a sense of their work as contributing to other people's learning and as such they are viewed as language experts. Yet, very often it is possible to observe a sense of illegitimacy related to L2 teachers' proficiency because of a strong held belief that 'native speakers' are better teachers as they might have superior knowledge of the language and related language teaching methodologies (Block, 2014). This is related to the native-speakerism ideology common in foreign language teaching in general, and pervasive in English language teaching (Holliday, 2006). This ideology is "characterized by the belief that 'native-speaker' teachers represent a 'Western culture' from which spring the ideals both of the English language and of English language teaching methodology" (Holliday, 2005 cited in Holliday, 2006, p. 385).

In contexts such as South America, specifically in Chile and in Brazil, where English plays a key 
role in the development of these countries as the most important (and often only) foreign language taught in schools (Finardi , 2016), the way foreign language teachers develop their identities has been under-researched, despite some relevant exceptions (e.g., Denardi, Souza Machado, \& Camilotti, 2017; El Kadri, 2018; Reis, Veen, \& Gimenez, 2011). In order to address this gap, this paper reports on a research study exploring the emerging identities of foreign language pre-service teachers in Chile and in Brazil during their practicum. This article aims to contribute to advance the discussion on teachers' identities further revealing particularities of the context from the expanding circle (Kachru, 1985).

\section{Defining the Concept of Identity}

The concept of identity has been defined from different perspectives and disciplines such as philosophy, psychology, and education. However, as a concept it still remains difficult to grasp, especially in L2 teacher education (Barkhuizen, 2017; Mora, Trejo, \& Roux, 2014). Yet this study is framed by a series of theoretical and conceptual underpinnings that shed light on how pre-service teachers develop their selves as foreign language teachers in Chile and in Brazil. In accordance with Norton's definition, identity is a process in which "a person understands his or her relationship to the world, how that relationship is structured across time and space, and how a person understands possibilities for the future" (Norton, 2000, p. 5). This means that an individual's identity is dynamic, contextual, and in relation to others. To this extent, identity can be viewed as "a process of continual, emerging and becoming" (Miller, 2009, p. 173), in which people construct who they are as they engage in different social activities.

Furthermore, identity "reflects the social, historical and political context of an individual's lived experiences" (Hall, 2002, p. 31); it is not a sole identity, but identities, related to different traditional demographic categories such as ethnicity, race, nationality, migration, gender, social class, and language. In the case of foreign language teachers, the foreign language plays a key role in their identity as it acts as a marker that they embody as multilingual speakers. In this sense, learning a foreign language is learning to be different. As Brown (1980) highlighted:

becoming bilingual is a way of life. Every bone and fiber of your being is affected in some way as you struggle to reach beyond the confines of your first language and into a new language, a new culture, a new way of thinking, feeling and acting. (p.1)

This observation implies that people adopt a world view and a specific type of life shaped by the foreign language learned.

The position that the foreign language plays in society shapes L2 learners, too. In the case of the English language, it has been observed that English has become more powerful in its growing presence as the lingua franca of globalization (including in Chile), making the role of English increasingly problematic in the neo-liberal era. In Brazil, scholars are growingly aware of the many roles and impacts that English has (Finardi, 2016) on different aspects of social life and education. Hegemonic power of a dominant and dominating language: cultural disorientation forces critical reflection on the ideological power of language as a tool of cultural imposition (Fairclough, 1989). Yet we can assume that the primary level of engagement (and actual real interest in English) is more cultural than economic: such as accessing cultural artefacts of the global North $^{5}$ such as music, cinema, and literature. This effect has been further expanded by rich affordances offered by the internet to access the cultural capital of the global North (Menard-Warwick, 2010).

\section{Foreign Language Teacher Identity}

Teacher identity is not only a fixed self-image, but also an image recognized by the community as a teacher (Danielewicz, 2001). Thus, being a teacher is a matter of being seen as a teacher by oneself and by others; it is also a matter of negotiating an identity that is socially legitimized (Beijaard, Meijer,

\footnotetext{
5 Sousa Santos defines the global North as geopolitical, rather than geographical concept referring to those developed/central countries which are concentrated either in the geographical North or South, as is the case of Australia and New Zealand whereas the global South refers to countries which are periferic (Sousa Santos, 2011).
} 
E Verloop, 2004). In the case of foreign language teachers, the community is extended beyond the borders of the school. The association between mastering the language and being an effective foreign language teacher has been widely accepted internationally (Freeman, 2017). This has been emphasized further as in some countries, national standards for foreign language teachers include an advanced level of proficiency in the target language, such as $\mathrm{C}^{6}{ }^{6}$, as it is the case of English Chilean teachers and English Brazilian teachers who are part of the English without Borders ${ }^{7}$ internationalization program.

A seminal study on teachers' identity is that of Pavlenko (2003) which reported on the imagined communities of pre-service and in-service teachers through the analysis of their linguistic autobiographies. The participants of this study came from different parts of the world and were students of an international MA TESOL. The results of this study suggested that teachers claimed memberships to the native teachers' community, non-native teachers' community, and multilingual/L2 users' community. This study provides a comprehensive discussion of the deficit view that some language teachers developed of themselves as a result of the dominating view of native speakerism as a standard to be achieved by FL teachers (Block, 2014).

In the same line, Beckett and Stiefvater (2009) suggested that there is a tendency for nonnative English-speaking teachers of English to see themselves as not able to teach colloquial English as they do not have an advanced sociolinguistic competence. This confirms the issue of proficiency in the English language as one of the key characteristics of a good language teacher, discussed earlier. Lee (2010), for example, illustrated how proficiency in the English language was considered the most important characteristic of a good teacher of English in Japan. This author argued that language proficiency influences professional image and undermines teachers' confidence.

6 C1 corresponds to the second highest level (Effective Operational Proficiency) of the European Framework of Reference for Languages (CEF or CEFR)

7 http://isf.mec.gov.br/idiomas/ingles
In South America in general, and despite some recent studies (see Denardi, Souza Machado, E Camilotti, 2017; El Kadri, 2018; Reis, Veen, $\varepsilon$ Gimenez, 2011), there seems to be room for more research on how FL teachers develop their identity. Indeed, an emerging body of literature has emerged in the last decades. The study of Mora, Trejo, and Roux (2014) provides some relevant insights by examining the interplay between professional development, identity and agency, and the role played by English language teaching certificates in the Mexican context. This study drew on the cases of two English teachers in Mexico undertaking a professional development program. The results of this study revealed that teachers, after having successfully completed their certificate of English, reported increases in their level of confidence, encouraging them to continue further studies. In the same vein, Barahona (2015) reported on a group of pre-service English teachers constructing their identities during their practicum in a Chilean teacher education program. This study demonstrated that for most of the pre-service teachers, their identities as language teachers were multiple and conflicted. Proficiency in the language was acknowledged as a key factor as well as a concern for their future performance as a teacher. However, other issues such as being a change agent was also part of the reported identities.

In Colombia, the study by Viáfara (2016) specifically examined participants' self-perceived (non)nativeness as speakers of Spanish and English and reported that most prospective teachers feared the disadvantages of not achieving native-like abilities. In Brazil, a number of studies (Denardi et al., 2017; Kalaja, Barcelos, Aro, \& Ruohotie-Lyhty, 2015) have confirmed that FL teachers reveal conflicted and multiple identities and that teachers' beliefs about FL language learning are closely related to their identities.

Thus, foreign language teacher identity formation can be conflicting as pre-service teachers have to make sense of varying and competing views of what language teachers should know, do, and be (Beijaard et al., 2004). In this sense, we suggest that language teacher identities are about negotiating new subject positions at the crossroads of the past, 
present, and future. Teachers are shaped by their socio-histories as life goes on (Hall, 2002).

\section{Foreign Language Teachers'Agency}

Human beings have solely "the capacity to act purposefully and reflectively on their world" (Rogers \& Wetzel, 2013, p.63). It is their cognitive and symbolic capacities that make them a conscious agentive species enabling actions to be transformative of the course of their lives in any given circumstance. Generally, human agency is intentional, forethoughtful, self-reactive, and selfreflective (Bandura, 2006) and individuals adapt and draw purposes on those bases.

The exercise of agency, however, is far more complex than simply having the personal desire to act. Social structures, context and power relations, as external factors, may downplay one's agentive capacity, not to mention internal and subjective factors. Furthermore, agency is closely linked with concepts like motivation (Bandura, 2006), positioning (Davies \& Harré, 1999; Kayi-Aydar, 2015), investment (Darvin \& Norton, 2016; Norton, 1995, 2013), and autonomy (Benson \& Huang, 2008; Toohey \& Norton, 2003), all of which highly capable to influence the subject's agentive capability. In sum, agency means the powerful potential of action that each subject has in a given social and cultural context. As a form of exercising power, agency is the expression of ones' positioning in the socially constructed world.

Thus, agency is a primary source within the negotiation of one's identity. As mentioned before, identity, as a constructed, multiple, diverse, and changing concept, is highly influenced by an individual's everyday acts. Particularly in educational settings, learners and teachers build their identity not only through concepts of the self, but through the complex and interrelated social context, mechanisms of power, and human agency. As acknowledged by Norton (2010), "while some identity positions may limit and constrain opportunities for learners (and teachers) to speak, read, or write, other identity positions may offer enhanced sets of possibilities for social interaction and human agency" (p. 351).
Teacher agency is relevant in the construction of teacher identity considering that a teacher is not a neutral player in the binomial teaching and learning relationship. Teachers' professional, social, cultural, political, linguistic identities, self-claimed or assigned by others, impact directly on teachers' practices by their capacity to act meaningfully and purposefully in any given situation. In other words, when they are positioned as agents.

So as to offer a glimpse of how these issues may be interpreted in FL teacher education in two countries of the global South, the next section describes the research study exploring the emerging identities of English as foreign language pre-service teachers during their practicum courses with two cases in Brazil and one in Chile.

\section{The Study}

A multiple case study was used to answer the following research questions:

1. What are the emerging identities that FL preservice teachers develop during their practicum in three different contexts?

2. How do FL pre-service teachers develop/ construct these emerging identities during the practicum?

3. How does the practicum experience mediate FL pre-service teachers' development of teachers' identity?

A case study approach enables the possibility of not only capturing action of individuals, but also understanding their motives and intersections with broader sociocultural demands (Merriam, 2009). This design assumed a bounded system or a case (or multiple cases) over time through detailed, indepth data collection involving "multiple sources of information rich in context" (Creswell, 1998, p. 61). The strength of the multiple-case studies design lies not only in its ability to demonstrate consistent patterns, but also in its ability to uncover new or divergent themes. The study included three cases in which the emerging identities of foreign language pre-service teachers were examined. 


\section{Methodology}

The research questions are addressed at the separate sites using different research designs. Each case used a range of methods of data collection including surveys, interviews, and observations. Each case study benefitted from one of these methods and participants have been selected due to their engagement with the practicum as preservice teachers. Interviews and class observation were conducted upon previous signed consent with all participants and recorded for later transcription. In all three cases, data followed a discourse analytic approach from which the emerged categories helped us understand the process of building a teacher's identity based on activities developed during pre-service momentum. As a dialogic exercise, participants' points of view are confronted with the notions of language proficiency, native and non-native speaker, and agency in order to portray their foreign language teacher identity.

The first case analyzes the beliefs of Brazilian pre-service teachers of English as a foreign language in relation to what they teach and its function in the formation of teachers' identity. It draws on data from class observations, interviews, and questionnaires in an English teaching degree course in a Federal university in Brazil. The second study, also in Brazil, analyzes the extent to which the idealized teacher's practice is legitimized in terms of foreign language proficiency. This second study draws on interviews with foreign language pre-service teachers enrolled in three different language teaching degree programs (English, French and Spanish) in a different Federal University . The third study maps out the emerging identities and contradictions of a group of Chilean EFL pre-service teachers during their practicum drawing on interviews and observations.

\section{Limitations}

Although a multiple case study proved to be sufficiently robust to address the research questions, it also presented some limitations. First, participants in the three research sites were undertaking the practicum under different working conditions (e.g., number of hours at schools, activities required and assessment). Second, each case drew from different types of data which made comparisons more difficult. Finally, the researchers were not completely aware of the particularities of the other sites. Thus, it is important to consider that the results of this study cannot be generalized to other contexts, but the value of the study lies in providing a situated understanding of the formation of FL teacher identity.

\section{Results and Discussion}

\section{Case 1: Brazilian EFL Pre-Service Teachers' Identity}

Contexts and participants. Participants were 19 pre-service English teachers, aged between 20 and 25 years old. Most had learned English before entering their English teaching degree program, one learned English in a public school, two in a private school, nine in a private language institute, four learned English independently, and nine learned English in a combination of more than one of these contexts. Seventeen out of 19 had some experience teaching English in private language institutes. When asked why they had chosen ELT in their university entrance examination test, five said that they wanted to learn English but not necessarily to become a teacher, five said that they wanted to become an English teacher, two said they were already teaching and wanted to become a certified English teacher, and seven said they had chosen this career for other unspecified reasons.

Findings. According to these pre-service teachers, the ultimate goal of the practicum course should be to train teachers to teach a language, to present/discuss approaches and methods of language teaching, and to reflect about methods and implications of teaching English. We can see from this account that these EFL pre-service teachers did not see the practicum as having a direct relation in the formation of their teacher identities since none of the participants mentioned how their identities were affected by the practicum.

Regarding their self-evaluation in terms of proficiency in English as a foreign language, 10 preservice teachers said that they saw themselves as 
English teachers, users and learners, four said they saw themselves as language learners, three said they saw themselves as language users, and only two said they saw themselves mainly as English language teachers. This piece of data is important because it shows that their identity as English teachers is linked or perhaps embedded in other identities of language users and learners.

When asked about which contexts they thought would be more probable for their students to use English in the future, 10 said that with native speakers through travel abroad and tourism in Brazil, five said that with non-native speakers through travel abroad and tourism in Brazil, seven said that with native speakers in the internet, and 10 said that with non-native speakers on the internet. Overall, we can see that these pre-service teachers are aware of the contexts where English might be used in Brazil, though many teachers still aim at preparing their students to interact with native speakers of English.

As part of the discussions during the practicum course, pre-service teachers were presented with some metaphors related to language teachers. The idea of presenting the metaphors to this group was to try to unveil which of the metaphors were more closely associated with pre-service teachers' identity. Participants in this study were asked to specify the metaphors and the extent to which they best described the way(s) they saw themselves and their work. The metaphors presented were: party host, manager, language advisor, source, judge, and needs analyst. Results of this activity showed that all participants see themselves as language advisors and source, though in different degrees as can be seen by the actual responses (see Appendix A). By triangulating these results with answers to previous questions , we can say that the role of language advisor and source is related to the view of English as being a foreign language and the role of the English teacher as being mostly to provide a model (source) to the language of the other.

Participants were also asked to relate to different roles as English teachers, and three said they related to the role of input or model provider, 15 said they thought of themselves as being responsible for providing opportunities for interaction in the L2, and only one participant said he thought of himself as a language corrector. Thus, most pre-service teachers see themselves as being responsible mostly for providing opportunities for interaction in the L2, whereas only three see themselves as legitimate models of the language. Again, this may be related to how teachers view the language and their proficiency level in relation to it, as previously suggested.

The analysis of participants' answers to the questionnaire suggests that these pre-service teachers' beliefs are more associated with the role of English as foreign language than that of English as a lingua franca or as an international language appropriated by Brazilians (Finardi, 2014). In regards to their identity construction, results suggests that these Brazilian pre-service teachers of English still see themselves as having multiple identities (teachers/users/learners) in relation to English and depending on their level of proficiency in the language. This result is perhaps related to the fact that these participants are still affected by notions of idealized proficiency levels as linked to native speakers of the language (Finardi, 2014).

Regarding the three research questions proposed for the macro study presented here, it is possible to say that the emerging identities of these pre-service teachers (of language instructor, source, and opportunity providers) develop during their life and their practicum course as a function of their views on the language taught, the ideal proficiency level for foreign language teachers, and the role of language teachers. In regards to the second research question, namely, how FL preservice teachers develop these emerging identities during the practicum, it is possible to say that they do so both as a consequence of their interaction with others and with themselves as language teachers during both the theoretical and practical part of the teaching practicum and as a result of the discussions and reflections afforded by the course. Finally, the third research question related to the mediation of the practicum experience in the development of pre-service teachers' identity and, based on the observation of this course, we suggest that the experience of the practicum with colleagues, theoretical discussions, and practice in real teaching 
contexts is an important form of mediation and teacher identity construction.

\section{Case 2: FL Teacher's Identity in Brazil: Between Idealized and Legitimized Proficiency}

Contexts and participants. Participants were 15 pre-service teachers of three different foreign language teaching programs (English, French, and Spanish), all undertaking their practicum course. Participants' ages ranged from 20 to 30 years old. In the English teaching degree program, participants were already fluent in the language. In the other two language teaching courses, the groups were very heterogeneous but with an overall low level of language proficiency. Beside the individual aspect, this scenario has historical and political roots and it is also the result of the language policies enforced in Brazil during the last fifty years, oscillating from a promotion from one language to another in public education, with the decline of French and more recently Spanish and the strengthening of English (Archanjo, 2016).

Data were collected in the context of a course in the last semester of the foreign language teaching program. Data came from interviews and questionnaires centered around four questions: (1) What does it mean to teach foreign languages today? (2) Who is the language teacher? (3) What kind of knowledge is necessary for this teacher? (4) What level of foreign language proficiency should a language teacher have? The three language groups (English, French, and Spanish) had their responses organized according to categories gathered from the data and not according to the language group. Whenever a categorization appeared to be exclusive to one language group, it has been highlighted.

\section{Findings}

Teaching foreign languages today. One critical concept that emerged from the data has been described as languaging. In broad terms, this is understood as "a dynamic, never-ending process of using language to make meaning" (Swain, 2013, p. 96). As a social practice, this concept suggests that that pre-service teachers benefit from this process of meaning-making by the shaping of knowledge and their experiences through language practice (Swain, 2013). Reflecting this, participants' responses were grouped into four themes: a challenge, the undisputed relationship between language and culture, a matter of methodology, and a global practice. In their own words:

\begin{abstract}
A methodology: "Knowing how to use available resources in order to give dynamic, fun, interesting and attractive classes."

The language and the culture: "A competence to unveil a new world through language and culture."

A challenge: "It is a challenging process. It means being flexible and adaptable."

A global practice: "Opening personal and professional ways. It is to place oneself in the world."
\end{abstract}

The language teacher. Three categories emerged from participants' responses a professional, an instrument, and a symbol of dedication. Participants pointed out the complex nature of their future practice whether focusing more in the type of skills necessary to it or to its subjective or symbolic attributes.

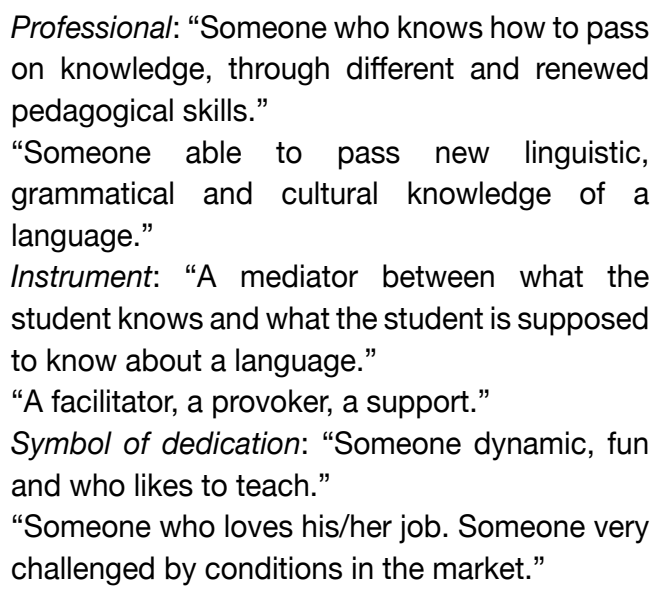

Professional: "Someone who knows how to pass on knowledge, through different and renewed pedagogical skills."

"Someone able to pass new linguistic, grammatical and cultural knowledge of a language."

Instrument: "A mediator between what the student knows and what the student is supposed to know about a language."

"A facilitator, a provoker, a support."

Symbol of dedication: "Someone dynamic, fun and who likes to teach."

"Someone who loves his/her job. Someone very challenged by conditions in the market."

Participants agreed that language skills are important, yet there are aspects beyond the technicality of the practice recognized as part of the endeavor to become a teacher and which they see as important as any other. As teacher-learners 
(Pennycook, 2004), a great deal of those beliefs comes from students' own ideologies and personal experiences. Memories of teachers they have had, of teachers they admire or despise, and idealized figure of the teachers they want to become.

The knowledge base. Pre-service teachers were also questioned about the basic standards for FL teachers. Their responses pointed to two main categories: linguistic competence and training. All of the participants highly stressed the importance of being fully competent in the language, to know about the language, and to know effective language teaching strategies. Examples of their responses included:

\footnotetext{
"Be linguistically competent"

"Knowledge of the language and its details. Knowledge of methodology and strategies for learning and teaching."

"Academic training, global and efficient teaching techniques. To know how to motivate and evaluate students."

"Coherence. High standards of ethical and professional knowledge."

"Multifarious training: linguistic, cultural and literary. Good pedagogy."

"Everyday up to date and continuous training."
}

For the majority of the participants, the FL teacher does not become a complete professional unless they possess the necessary linguistic competence and the adequate training which, for more than one participant, is an on-going and a never-ending process.

FL proficiency. Pre-service teachers' reflections on the proficiency of the target language were categorized into four themes indicating not only their current stage of development but also their vision for the future as well as their perceived agentive capacity. The first category represents what participants believe to be the necessary proficiency level for FL teachers. As they expressed: "The proficiency level must be excellent"; "A language level that allows teacher to communicate fluently." Indeed, participants remained in line with their previous assumptions regarding the obvious importance of good competence in the matter of their practice.
The second category, the desired level, expressed some interesting thoughts about how participants were feeling about themselves. Some preferred to be more cautious and say that "language fluency was desirable" or that "an advanced level would be desirable," meaning that sometimes you may not have it, but you have to make it work with what you have. In many cases, this is the legitimized proficiency of FL teachers in contexts where, in looking backward, student's background is deficient and, in looking forward, the professional demands won't be challenging enough. This particularly relates to the reality within Brazilian public schools where the quality of the instruction is questioned with an interchangeable set of responsibilities posed on either the teacher's instruction and the students' interest and motivation (Gimenez, 2009).

Accordingly, the third category pointed to the real level of FL proficiency. Pre-service teachers revealed a sharp image of their reality and of the challenges faced by them in their practicum: "More than often, in reality, the proficiency level is never the one expected (lack of content, lack of fluency in the language and culture which results in a poor class)." Emphasizing the working place, some participants argued: "In reality, this will depend on where the teacher will work," or in the same line: "The level of language proficiency of the teacher depends on the level of the students." Another set of responses clearly pointed out that: "In reality, not all professionals in FL (teachers) have a good language level."

The last category was entitled improvement and correlates with student agency. In the construction of their identity as language teachers, they become conscious very early that they have to work on their language competence and that a language teacher is in permanent reinvention of itself. This is perceived by some of the participants' responses stressing that: "What is important is to study continuously to reach an ideal language level"; "What is really important is to continuously improve."

Drawing on the concerns expressed by the preservice teachers engaged in this case study, the process of building the identity of a FL teacher can be conflicting depending on their trajectory along 
the course. Some student-teachers start developing their identity as teachers right from their first year. The practicum experience can mediate the development of teachers' identity as long as it provides a space for students to clarify perceptions, to make choices, and to engage in changes. In accordance with Pennycook (2004) teacher practicum should not be viewed as:

a period in which teacher-learners practice the techniques they have learned in their university courses; rather, this is a time for teacher-learners to try to reconcile three competing domains: the knowledge and ideas gained through their formal study; the history, beliefs, and embodied practices they bring with them; and the constraints and possibilities presented by the particular teaching context. (p. 334)

\section{Case 3: From Students to (language) Teachers: A Case Study in Chile}

Contexts and participants. Participants were final stage students of a five-year English teaching program in Chile. Their ages ranged from 21 to 25 years old and the majority of them were female. As part of their final year of studies, they were undertaking their final practicum which consisted of $12-15$ weeks of teaching in K-12 schools. These participants had undertaken two previous formal teaching experiences at schools with different levels of engagements. In the first teaching experience, they mainly observed the school context and learned about the students' characteristics and, in some cases, they collaborated with the teacher monitoring students' work or marking tests and designing material. For the final practicum, these pre-service teachers were requested to take the responsibility of teaching two grades for a whole semester (around 15 weeks). The activities included: planning, material design, teaching, assessing students' work, marking tests, and collaborating with the teacher mentor in other activities at school.

The data presented in this paper comes from a larger project which intended to explore collaborative ways to support pre-service teachers more effectively. The data were drawn from interviews and observations of pre-service teachers in the school context that specifically explored the relation between language and identity and their enactment of teacher identity during their practicum. Findings are presented according to three main categories: motives to become English teachers, learning to teach a FL, understanding the role and impact of the practicum, multiple and conflicted 'identities

\section{Key findings}

Motives to become a teacher of English. Most of the participants reported that they had enrolled in the English Language teacher education program because of their interest in learning English. They saw the program as one possibility in which they could develop their skills in the English language and use these skills for different purposes including tourism and teaching. Some also mentioned that they were motivated by their strong desire to transmit their passion for a foreign language to younger generations. Others also reported that although they had enrolled because of their interest in English, throughout the years they had developed a stronger sense of what teaching English meant, and their perceptions have changed.

Pre-service teachers' responses confirm a wellresearched tendency among FL teachers in that they are drawn by their interest in the target language and its cultural manifestations (Kalaja, Barcelos, Aro, E Ruohotie-Lyhty, 2015).

Learning to teach a FL: 'In transition' and 'in between.' Most pre-service teachers reported that they felt 'in transition' to becoming a teacher, but still they identified as students, 'in between' the university and the school, and 'in between' their aspirations and what reality demonstrated. This was evidenced through pre-service teachers' responses about their objectives as future English language teachers and how these were related to their practicum experiences. In most cases, they confessed high levels of frustration in terms of their aspirations as being unreal and impractical for the Chilean schooling context. In this sense, some reported that communicative language teaching approach was very difficult to implement because of school constraints (i.e., number of students, textbook, teacher mentor's guidelines). However, others reported that the implementation was because 
of their lack of proficiency in the target language or due to a lack of confidence in implementing communicative tasks in the classroom. Yet, most of these pre-service teachers' proficiency levels were highly advanced (B2-C1 according to the Common European Framework of Reference for Languages).

Understanding the role and impact of the practicum. The practicum was seen by most of the pre-service teachers as a space where they could articulate theory and practice. They recognized that the practicum experience was probably the most meaningful experience in relation to their teaching skills as they could face the daily challenges a teacher faces and they could put into practice what they had learned. In this sense, these pre-service teachers understood that learning to teach comprises situated and experiential knowledge. However, most pre-service teachers also revealed strong mixed feelings about the outcomes of the practicum. Some reported that their lived experiences in schools were loaded with stress and overwhelming feelings. At times they felt they were unable to successfully teach and comply with all the requirements including the sometimes contradictory messages they received from the school and university.

Most pre-service teachers valued the sessions of the practicum course devoted to sharing their experiences and the time for reflection on those experiences. They even said that they looked forward to that weekly session as it was the only instance where they could express what they were going through at school and equally discuss some strategies to face those challenges.

'Multiple and conflicted' identities. The second round of interviews and observations of pre-service teachers at schools were focused on the actions and activities they undertook and how these related to their pedagogical decisions. The analysis revealed three main categories of their emerging identities: I'm a teacher, I'm a foreign language teacher, and I am a language learner.

I'm a teacher (change agent): This category refers to the teacher who feels that their role is to educate holistically her students beyond the discipline. Her work is orientated towards students' welfare and it is not necessarily guided by language teaching. In some cases, some pre-service teachers tended to see their responsibility to educate learners as something disjointed from teaching a FL as observed in the following comment :

I'm a foreign language teacher: This refers to a strong sense of a teacher as a facilitator/bridge between languages and cultures. Their actions are guided by their strong desire to contribute to students' learning of the foreign language. However, there is a tendency for a teacher to not feel fully legitimate as they are not confident in their proficiency in the foreign language.

I'm a permanent language learner: This category refers to their identification to their language expertise as their strength. Their actions are guided by their own interest in continuing learning the language and looking for possibilities in which they could use the language rather than by using that expertise in their pedagogical decisions. As a language learner, there is a tendency of aspiring to sound (and be like) a 'native' English speaker undermining their confidence as a FL teacher.

These categories are not mutually exclusive, as they were present at different moments in the lived experiences of these pre-service teachers and they were apparent in constant interaction with others. Pre-service teachers' identities were conflicted between being a (permanent) language learner and a language teacher, and between language teaching and teaching to socially transform society. In this sense, learning to teach a FL is in part a process of constructing an identity in the midst of systems of relations. During the practicum, preservice teachers were involved in overlapping, often conflicting activity settings that make this identity formation quite challenging (Cook, Smagorinsky, Moore, Jackson, \& Fry, 2004).

\section{Conclusions}

The cases reported here confirm that foreign language teacher identity is a complex phenomenon that is not fixed, but it is multiple, shifting, in conflict and in activity (Dang, 2013). Teacher identity 
is context bound, and closely related to social, cultural, and even political links. Teacher identity is constructed, maintained, and negotiated in a community through discourse and social practices and is inherent to learning to teach a foreign language as a professional activity.

The cases reported in Brazil reveal that proficiency is still considered a major factor in the construction of FL language teachers' identity. Although language proficiency is clearly something that students can develop during their professional path, elements such as the still prevalent myth of the native language teacher as the ideal to reach may undermine their effort. In this study, the analysis brought to bear the conclusion that the more preservice teachers are able to share their experiences and beliefs during initial teacher education, the more they boost their chances to overcome this idealized goal to attain native-like proficiency. Moreover, agency appears as a key factor in reducing inequalities historically tied to the ideal of linguistic competence. Participants feel that being a teacher is an ongoing process which does not end with their degree. Building a teacher's identity, whether during their studies or after in their professional practice, is strongly linked to their investment and their agentive capability to position themselves as teachers.

Indeed, the case situated in a Chilean teacher education program specifically confirms that one of the challenges in this process of learning to teach is the oscillating nature of identifying themselves as students and as teachers. This transition to a strong teacher identity is a slow and recursive process; it is rarely direct and depends on multiple interactions with others, as emerged in all three cases. Through the practicum, pre-service teachers experience the role of being the teacher first with students, and later they fully embrace being the teacher within themselves.

In conclusion, we can affirm that foreign language teacher identity in the context of the global South is still shaped by notions of legitimization and language proficiency, mostly dictated by the global North. It seems that contextual issues and local needs are poorly addressed in FL teacher education programs, transferring to 'teachers to be' the responsibility to take upon themselves the necessary effort to integrate theory and practice. Since this cannot be taken for granted, in the three cases studied, teacher identities often seem to reinforce structural inequalities in the relationship between languages and their promotion.

Overall, this study contributes to the body of literature that supports the assumption that one does not become a FL teacher by only learning the target language and learning about the language, but one becomes a FL teacher building their practice through the construction of a teacher identity. As such, one implication of this study for foreign language teacher education programs is to reflect upon the identities that FL teacher education programs are promoting and the role of foreign language teachers in relation to global and local contexts. The results of this study might be used by curriculum designers, practicum supervisors, policy makers, and language teacher educators as a basis to restructure curricula and standards for FL teachers. It is advisable that more situated research on FL teachers' identity is undertaken to reveal the practices and realities of teachers in Latin America.

\section{References}

Archanjo, R. (2016). Saberes sem Fronteiras: Políticas para as migrações Pósmodernas. DELTA, vol.32, no.2, p.515-541. ISSN 0102-4450 https://doi.org/10.1590/01024450790718885409696

Barahona, M. (2015). English Language Teacher Education in Chile: a Cultural Historical Activity Theory Perspective. Abingdon, Oxon: Routledge. https://doi.org/10.4324/9781315689937

Finardi, K. R. (2014). The Slaughter of Kachru's Five Sacred Cows in Brazil: Affordances of the Use of English as an International Language. Studies in English Language Teaching, 2, 401411. https://doi.org/10.22158/selt.v2n4p401

Finardi, K. R.(2016) English in Brazil: views, policies and programs. 1. ed. Londrina: EDUEL, v. 1. 232p.

Bandura, A. (2006). Toward a psychology of human agency. Perspectives on Psychological Science, 1(2), 164-180. https://doi.org/10.1111/j.17456916.2006.00011.x 
Bauman, Z. (1999). O mal-estar da pósmodernidade. Rio de Janeiro: Zahar

Barkhuizen, G. (2017). Reflections on language teacher identity research. New York, NY: Routledge.

Beckett, G. H., \& Stiefvater, A. (2009). ESL graduate student perspective change on a non-native English speaker Teacher. TESL Canada Journal, 27(1), 27-46. https://doi.org/10.18806/tesl. v27i1.1028

Beijaard, D., Meijer, P. C., \& Verloop, N. (2004). Reconsidering research on teachers' professional identity. Teaching and Teacher Education, 20(2), 107-128. https://doi. org/10.1016/j.tate.2003.07.001

Benson, P., \& Huang, J. (2008). Autonomy in the transition from foreign language learning to foreign language teaching. D.E.L.T.A., 24:esp., 421-439. $\quad$ https://doi.org/10.1590/S010244502008000300003

Block, D. (2014). Second language identities. London: Bloomsbury Publishing.

Brown, H. D. (1980). Principles of language learning and teaching. New York, NY: Longman.

Cook, L. S., Smagorinsky, P., Fry, P. G., Konopak, B., \& Moore, C. (2002). Problems in developing a constructivist approach to teaching: One teacher's transition from teacher preparation to teaching. The Elementary School Journal, 102(5), 389-413. https://doi. org/10.1086/499710

Creswell, J. W. (1998). Qualitative inquiry and research design: Choosing among five traditions. Thousand Oaks, CA: Sage Publications.

Dang, T. K. A. (2013). Identity in activity: Examining teacher professional identity formation in the paired-placement of student teachers. Teaching and Teacher Education, 30(0), 47-59. https:// doi.org/10.1016/j.tate.2012.10.006

Davies, B. E Harré, R. (1999). Positioning and personhood. In R. Harré, \& L.v. Langenhove (Eds.), Positioning theory (pp. 32-52). Location : Wiley-Blackwell.

Darvin, R., \& Norton, B. (2016). Investment and language learning in the $21^{\text {st }}$ century. Langage et Société, 157(3), 19-38. https://doi.org/10.3917/ ls.157.0019

Danielewicz, J. (2001). Teaching selves: Identity, pedagogy, and teacher education. Albany, NY: State University of New York Press.
Denardi, D., Souza Machado, E., \& Camilotti, C. (2017). A (re)construção da identidade do professor de língua inglesa sob a ótica de pesquisadores paranaenses. Paper presented at the VI Congresso Latino-americano de Formação de Professores de Línguas, Londrina. Brazil. https://doi.org/10.5151/eduproclafpl2016-020

El Kadri, M. S. (2018). The Pibidian identity: A critical discourse analysis of the social actor Pibidian in teacher education programs. Acta Scientiarum. Language and Culture, 40, 1-11.

Fairclough, N. (1989). Language and power. New York, NY: Longman.

Freeman, D. (2017). The case for teachers' classroom English proficiency. RELC Journal, 48(1), 31-52. https://doi.org/10.1177/0033688217691073

Gimenez, T. N. (2009). Diretrizes curriculares e a sala de aula de língua estrangeira: Diálogos (im)possíveis? In D. A. Correa \& P. B. O. Saleh (Org.), Estudos da linguagem e currículo: Diálogos (im)possíveis (pp. XX-XX ). Ponta Grossa: Editora UEPG.

Hall, J. K. (2002). Teaching and researching: Language and culture. Harlow: Longman.

Holliday, A. (2005). The struggle to teach English as an international language. Oxford: Oxford University Press.

Holliday, A. (2006). Native-speakerism. ELT Journal, 60(4), 385-387. https://doi.org/10.1093/elt/ ccl030

Kachru, B. B. (1985). Standards, codification and sociolinguistic realism: The English language in the outer circle. In R. Quirk \& H. G. Widdowson (Eds.), English in the world: Teaching and learning the language and literatures (pp. 11-30). Cambridge: Cambridge University Press.

Kalaja, P., Barcelos, A. M. F., Aro, M., \& RuohotieLyhty, M. (2015). Beliefs, agency and identity in foreign language learning and teaching. London, UK: Palgrave Macmillan.

Kayi-Aydar, H. (2015) Teacher agency, positioning, and English language learners: Voices of preservice classroom teachers. Teaching and Teacher Education, 45, 94-103. https://doi. org/10.1016/j.tate.2014.09.009

Lee, J. J. (2010). The uniqueness of EFL teachers: Perceptions of Japanese learners. TESOL Journal, 1(1), 23-48. https://doi.org/10.5054/ tj.2010.214881 
Menard-Warwick, J. (2010). Chilean English teacher identity and popular culture: Three generations. International Journal of Bilingual Education and Bilingualism, 14(3), 261-277. https://doi. org/10.1080/13670051003797466

Merriam, S. (2009). Qualitative research: A guide to design and implementation (Rev. E expanded ed.). San Francisco, CA: Jossey-Bass.

Miller, J. (2009). Teacher identity. In A. Burns \& J. C. Richards (Eds.), The Cambridge guide to second language teacher education (pp. 172181). Cambridge, UK: Cambridge University Press.

Mora, A., Trejo, P., \& Roux, R. (2014). English language teachers' professional development and identities. PROFILE: Issues in Teachers' Professional Development, 16(1), 49-62. https://doi.org/10.15446/profile.v16n1.38153

Norton, B. (1995). Social identity, investment, and language learning. TESOL Quarterly, 29(1), 9-31. https://doi.org/10.2307/3587803

Norton, B. (2000). Identity and language learning: Gender, ethnicity and educational change. Harlow, England: Longman.

Norton, B. (2010). Language and identity. In N. Hornberger \& S. McKay (Eds.), Sociolinguistics and language education (pp. XX-XX ). Clevedon, UK: Multilingual Matters. https://doi. org/10.21832/9781847692849-015

Norton, B. (2013). Identity and language learning: Extending the Conversation: Location : Channel View Publications. https://doi. org/10.21832/9781783090563

Norton, B. (2016). Identity and language learning: Back to the future. TESOL Quarterly, 50(2), 475-479. https://doi.org/10.1002/tesq.293

Pavlenko, A. (2003). "I never knew I was a bilingual": Reimagining teacher identities in TESOL. Journal of Language, Identity \& Education, 2(4), 251-268. https://doi.org/10.1207/ $\underline{\text { S15327701JLIE0204_2 }}$
Pennycook, A. (2004). Critical moments in a TESOL praxicum. In B. Norton $\&$ K. Toohey (Eds.), Critical pedagogies and language learning (pp. 327-345). Cambridge: Cambridge University Press. https://doi.org/10.1017/ CBO9781139524834.017

Reis, S., Veen, K. V., \& Gimenez, T. (Eds.). (2011). Identidades de professores de línguas. Londrina: EDUEL.

Rogers, R., \& Wetzel, M. M. (2013). Studying agency in literacy teacher education: A layered approach to positive discourse analysis. Critical Inquiry in Language Studies, 10(1), 62-92. https://doi.org /10.1080/15427587.2013.753845

Sousa Santos, B. (2011). A universidade no século XXI: Para uma reforma democrática $e$ emancipatória da universidade. São Paulo: Editora Cortez.

Swain, M. (2006). Languaging, agency and collaboration in advanced second language proficiency. In $\mathrm{H}$. Byrnes (Ed.), Advanced language learning: The contribution of Halliday and Vygotsky (pp. 85-108). London E New York: Continuum.

Toohey, K., E Norton, B. (2003). Learner autonomy as agency in sociocultural settings. In D. Palfreyman E R. Smith (Eds.), Learner autonomy across cultures: Language education perspectives (pp. 58-72). Basingstoke, UK: Palgrave Macmillan. https://doi.org/10.1057/9780230504684_4

Viáfara, J. J. (2016). "I'm missing something": (Non) Nativeness in prospective teachers as Spanish and English speakers. Colombian Applied Linguistics Journal, 18, 11-24. https:// doi.org/10.14483/calj.v18n2.9477

Weedon, C. (2004). Identity and culture. New York, NY: Open University Press. 